SHS Web of Conferences 10, 00012 (2014)

DOI: $10.1051 /$ shsconf $/ 20141000012$

C Owned by the authors, published by EDP Sciences, 2014

\title{
Collective memories and society integration issues in context of inter-generation dialogue
}

\author{
D. Hanovs
}

Rīga Stradinsš University, Latvia

\begin{abstract}
The article deals with the issue of society integration politics in Latvia, analyzing the question of collective memories becoming a tool for communication between generations on vital themes of Latvian memory politics, such as the issue of 1940 Soviet occupation, the so-called "Soviet times" (1945-1991) and the current activities of various political actors concerning minority rights in Latvia. The major stumbling block of the integration politics until recently has been unsuccessful politics of the past - various controversies of the $20^{\text {th }}$ century have not been treated dialogically, but rather misused by antagonistic political powers to create the negative Other of the political rivals. The result is two decades of a weak and unsuccessful dialogue on the Latvian past.
\end{abstract}

\section{Introduction}

Latest Developments of Society Integration in Latvia and Analytical Framework.

Since the beginning of the 1990ies Latvia has been moving towards the Western political culture. While being a part of the Soviet state, Latvian society underwent various crucial structural changes which have been of great significance after the breakdown of the USSR ${ }^{1}$. Not only were pre-war political and cultural elites of the country eliminated during various actions of the Stalinism politics in the 1940ies - mass deportations and arrests left massive collective traumas which were silenced during the Brezhnev period and came into political discourses as late as the beginning of perestroika period in the late 1980 ies $^{2}$.

Until now history of the $20^{\text {th }}$ century keeps its leading position in the political and even economic agendas in Latvia, shapes and also blocks various processes in the current Latvian society, such as interethnic dialogue and society integration. Latvian academic debates on society integration have entered the second decade, producing regularly various studies and analysis, political recommendations and research projects. One of the major actors in these debates has been the Society Integration foundation which was established in 2001 to support the integration politics. The Foundation tries to achieve two goals - support of civic activities of the Latvian ethnic minorities, which constitute about

\footnotetext{
${ }^{1}$ For details of the societal structural changes during the Soviet period 1945-1991 see: Okupācijas režìmi Baltijas valstīs 19401991: Latvijas Vēsturnieku komisijas 2008. gada pētījumi un starptautiskās konferences materiāli, 2008. gada 30.-31. oktobris, Rīga. - Rīga: Latvijas vēstures institūta apgāds, 2009. - (Latvijas Vēsturnieku komisijas raksti, 25. sēj.)

2 See for details on the so-called "third awakening" in the 1980ies: Stradiňš J. Trešā atmoda: raksti un runas 1988.-1990. gadā Latvijā un par Latviju. - Rīga: Zinātne, 1992.

This is an Open Access article distributed under the terms of the Creative Commons Attribution License 4.0, which permits unrestricted use, distribution, and reproduction in any medium, provided the original work is properly cited.
} 


\section{SHS Web of Conferences}

$40 \%$ of the Latvian population and is unevenly situated in the larger cities and towns of Latvia with Daugavpils and the capital Riga at the top. The other aim of the Foundation is to support long-lasting analysis of the integration politics, including media space, which, according to various Latvian scientists play crucial role in the integration politics and politics of the past ${ }^{3}$.

In this article, politics of the past will be defined as an integral part of the politics of integration in Latvia. According to French historian and sociologist, one of the founders of the paradigm of collective memory Pierre Nora, past exists within two confronting phenomena - history and memory, which have different, confronting functions in explaining the past to a person or a group, to a society in general. Nora defined borderlines between memory and history not according to the quality of their sources, but according to their functions ${ }^{4}$. History is a scientific, structured and "sterile" (if it is possible at all!) process of analysis, which removes collective emotions - fears, fantasies and tendency to create and sustain myths. All these functions can be traced back to collective memory and its role in creating collective meanings - Nora states that memory is emotional and can combine issues, dates and facts which are otherwise "expelled" from the realm of academic analysis of the past or are not logical. The concept of Nora is based on his attempts to rediscover and reinterpret the concepts of Morice Halbwachs, a French interwar period sociologist, whose various articles, but mainly his major work on "Collective memory" have created the basis for collective (cultural) memory schools in different European academic circles 5 .

Morice Halbwachs stated that no memories can occur in an individual mind except when delivered by collective experience and societal pressure on the "clean" individual memory ${ }^{6}$. No doubt, since the rediscovery of Halbwachs in French and later in Anglo-Saxon academic tradition, memory studies made a breath-taking breakthrough in various academic disciplines and now inhabit interdisciplinary area of social sciences and humanities, visual arts and even theology ${ }^{7}$. Among the most remarkable theoreticians of the cultural/collective memory paradigm are Jan and Aleida Assmann, who are treating collective memories in ancient classical cultures, Renaissance cultures and in European literatures of the $19^{\text {th }}$ century $^{8}$. One of the most important theses produced by Jan Assmann in the 1990ies concerns memory or mnemonic structures in their relations to collective identities and generations. According to Jan Assmann's memory classification, there are two types of collective memory and the difference lies in their ability to reach different age groups or generations. Assmann stated in his famous analysis "Cultural Memory" that there is a communicative memory, which unites in its meaning production process at least by three generations and there is also a cultural memory, which consists of events and personalities which had never been experienced directly but any of the three generations, such as mythical personalities and actors of ancient or medieval history. Both types of collective memory exist in specific forms, are transmitted by various media, reflect and construct time concepts and have two different groups of bearers or persons in charge of memory (Assmann uses the German term “Träger"). ${ }^{9}$

\footnotetext{
3 Details on the functions of the Society Integration foundation see the website of the Foundation: http://www.lsif.lv/ index.php?option=com_content\&view=article\&id=1\&Itemid=11\&lang=en (last viewed 20. January 2013).

4 Nora P. Zwischen Geschichte und Gedächtnis. - Frankfurt am Main: Fischer, 1998. - S. 13-14.

${ }^{5}$ For example: Apfelbaum E. Halbwachs and the Social Properties of Memory. In: Radstone S., Schwary B. (eds.) Memory. Histories, Theories, Debates. - Fordham University Press, 2010. - pp. 77-92.

${ }^{6}$ Halbwachs M. Collective Memory. See Chapter 5 of on-line version: http://web.mit.edu/allanmc/www/hawlbachsspace.pdf (version as of 1950) - p. 14.

7 See for example: Volf M. The End of Memory: Remembering Rightly in a Violent World: Cambridge: Eerdmans Publishing, 2006.

8 The major work of Jan Assmann on the issue of this article is: Assmann J. Das kulturelle Gedächtnis. Schrift, Erinnerung und politische Identität in frühen Hochkulturen. - München: Becksche Reihe, 1997.

9 Assmann J. Communicative and Cultural Memory. In: Erll A., Nünning A. (eds.). A Companion to Cultural Studies. - De Gruyter, 2010. - p. 117. The term appeared in the German version of the text on cultural memory: see note 6. - p. 56.
} 


\section{Int. Conf. SOCIETY. HEALTH. WELFARE.}

All these elements - forms, media, time concepts and bearers of memory are highly relevant to the Latvian case of integration politics. Let me mention just three major arguments in favour of this statement.

Firstly, Latvian society underwent very rapid changes two decades ago and is still in transformation process as a part of global changes. Although transformation of economics and political culture are still in progress, Latvians, irrespectively of ethnic origin and linguistic identities, have experienced a kind of political "hour zero" when almost half a century of Soviet political and economic structure finally and extremely quickly (I would suggest two - three days of the Janajev et altera coup d'etat in August 1991 in Moscow - as a time measurement unit) disappeared. In collective memories of Latvians this was the beginning of a new life or, rather the return to the old and forbidden independent state of the late 1930ies.

Secondly, the structural changes of society during extreme industrialization of the country in the 60ies and 70ies, which lasted until the mid of 80ies, introduced a unique situation which affected memory politics not only at the state policy level, but also at the level of everyday memory processes. In the situation of sudden end of political control over individual and collective memories mnemonic processes became various, plural - Jacques Le Rider in his essay on Central Europe as a place of memory (taking over the concept of Nora's lieu de memoire) stated that politics of memory and places of memory have been central elements of dissident politics - this is certainly true for Latvian case when Riga Forest Cemetery (Meža kapi) ${ }^{10}$ and the monument of Freedom in the centre of Riga ${ }^{11}$ became points of dissident resistance and alternative remembering during the Soviet time. ${ }^{12}$

Thirdly, the plurality of memories in a democratic society requires ways and tools of finding a common language not only for shaping political discourse on the past, but also on dealing with confronting memories in everyday discourses, which do not stay in private space but play an important role in various forms of direct democracy, such as referendum on the status of Russian language in Latvia, which took place on February 18, 2012 and was aimed at proclaiming Russian language another official language in Latvia. In this situation linguistic issue became an issue of clashes for interpretation of the past - on the one hand a symbolic revenge of the "suppressed" minorities, "supported" by a new political party "For Mother Tongue" (Russian - ЗАРЯ), on the other hand the "final" contest for the dominance of the Latvian language and culture in Latvia - so styled by central-right political wing and many representatives of Latvian ethnic cultural elites ${ }^{13}$.

But there is another, more important, issue to be dealt with within the integration politics - the past concepts can be not only generations dividing element, but can form a generation bridge, a suprageneration mnemonic structures to unite various generations within one distinct concept of collective memories, which may be very distant from academic version of the past.

\footnotetext{
10 During the Soviet times various graves of famous politicians and writers of the interwar period were in different ways made unaccesable. Putting flowers there was considered an act of political protest and was carefully noted by the KGB staff.

11 The monument replaced the equestrian monument of Russian Tzar Peter I. Lost after the First World War. After WW II there were plans to destroy the monument, but these plans were never put into practice thanks to the famous Soviet sculptur Vera Muhina. Putting flowers to this monument on November 18 (date of the foundation of Latvia) was considered an act of political disloyalty to the Soviet regime and could affect educational or career plans, for example a student who put flowers to the monument was dismissed from the university.

12 Le Rider J. Mitteleuropa as a lieu de memoire. In: Erll A., Nünning A. (eds.). A Companion to Cultural Studies. - De Gruyter, 2010. - p. 39, 41 .

13 Here are some of the latest articles on the issue of referendum written jointly with a colleague of mine from the University of Latvia: Hanov D., Tēraudkalns V. Denying the Other in the Cyber Space: Democracy and Political Culture in Latvia: Analysis of the Internet Campaign "For Mother Tongue" (November 2011)// Ethnicity 2012/6. - pp. 4-24. All PDF versions of the journal Ethnicity are available on-line on the website of Daugavpils University: www.du.lv (search for "ethnicity"); Extended version of the article with analysis of the latest campaign see: Hanovs D., Tēraudkalns V. New Diaspora Nationalism in Latvia? Russian Identity in Internet Campaigns "For Mother Tongue" (2011) and "Change the Law on Citizenship" (2012) // Scientiae et Patriae. Veltījums akadēmiíei profesorei Vairai Vīksei-Freibergai 75. dzimšanas dienā. / Cimdiña A., sast. Rīga: LU Akadēmiskais apgāds, 2012, pp. 147-164.
} 


\section{SHS Web of Conferences}

According to Jan Assman bearers of memory create and sustain generational gaps and create generation bridges mentioned above. To sum up the introduction part of the article, the following should be mentioned: both phenomena - generational gaps and bridges exist in Latvian memory space, which can be characterized as both ethnically and age divided memory space. What are the major elements of the Latvian memory landscape? Before turning to the overview of these elements in details in the next chapter, they should be merely touched upon here in few lines: there are memories of ethnic Latvians, in which traumatic experience of Soviet occupation and mass deportations are predominant, but do not exclude the existence of Soviet "positive" memories, although these are "down and out" of the official political and media discourse, except some examples of consumer society shaped products of nostalgia. Another set of memories exists predominantly among those ethnic minorities, whose ancestors or they personally settled in Latvia after 1940, the year of occupation, as a result of Soviet economic inner migration, education process, marital plans, etc. This group, which is far from being homogeneous is still shaped by its experience in Latvia of the 70ies and 80ies, especially what concerns the unofficial status of predominant ethnic group in Soviet Union - the Russian. What are the major mnemonic conflicts and how do these conflicts affect generational dialogue or conflicts in current Latvian integration discourse?

\section{Who remembers what? Conflicting memories in Latvia}

According to researchers Vita Zelče un Martinš̌ Kaprāns, who based their theses on the sociological opinion polls in the beginning of the 90ies, less than $30 \%$ of the respondents as children new that their parents suffered from the Soviet regime. ${ }^{14}$ Vita Zelče stated in the last Report on the Development of the Nation in 2011, that there are clear differences in the support for the idea that "the cohesion of Latvian society should be based on the idea of Latvian (ethnic) culture and Latvian language."15 The same survey shows that the common ground for Latvia's development is to be found in the area of civic rights and duties of a citizen, not in the predominance of culture of ethnic majority - thus respondents are mostly unanimous in their support for rule of law, fight against corruption and other social issues. ${ }^{16}$ Authors of the analysis formulated various proposals to enlarge the share of civic values in the integration policy in Latvia, as these values re shared by both ethnic "groups". ${ }^{17}$

Another important element of Latvian memory culture is the predominant image of Latvians as collective victim of the $20^{\text {th }}$ century regimes, mostly of the long lasting communism regime. ${ }^{18}$ This predominant collective self-image is being supported in regular circle of politically important dates, such as various days of remembrance of communism genocide, as well as deportations before and after 1945. The Latvian version of community of suffering is not unique, but is rather a local version of a global community identity based on collective trauma - the Jewish community shapes globally its collective identity through sufferings during the Holocaust, as Esther Benbassa stated in her analysis. ${ }^{19}$ Commemoration techniques in Latvia are concentrated on the image of the Latvian ethnic nation that suffered and, as Vita Zelče and Nils Muižnieks formulated in the volume "Combating memories", history has become a field for political activities, thus excluding those who really suffered or participated in the World War II from the event, which replaces mnemonic activities of the witnesses. ${ }^{20}$

\footnotetext{
${ }^{14}$ Kāprans M., Zelče V. (eds.) Pēdējais karš: atmiņa un traumas komunikācija. - Rīga: Mansards, 2011. - 21. lpp.

15 Latvija. Pārskats par tautas attīstību 2011. - lpp. 36. This report is available on-line: http://www.biss.soc.lv/downloads/ resources/TAP/Latvija_TAP_2011.pdf

16 Ibid.

17 The Report operates with traditional two larger and abstract groups such as majority and minorities wuthout specifying that there are about 145 ethnic minorities in Latvia and various groups have had their experience of living among ethnic majority. Also regional dimensions are rather understated.

18 Ibid. - lpp. 38 .

19 Benbassa E. Suffering as Identity. The Jewish Paradigm. London: Verso, 2007.

${ }^{20}$ Muižnieks N., Zelče V. (eds.) Karojošā piemiņa. 16. marts un 9. maijs. - Rīga: Zinātne, 2011. - lpp. 160, 170.
} 


\section{Int. Conf. SOCIETY. HEALTH. WELFARE.}

Memories of being a victim are repeated annually during the so-called march of the survived veterans of the Latvian SS Legion on March 16 in the centre of the Old Town in Riga, each year becoming a tool for political combats and media headlines. The history of the creation of the Legion is too complex to be reflected on several pages here, but one must be stated - the history of the Latvian soldiers forced to choose between two military powers, both equipped with effective terror and oppression system has become the tool for both, inter-generational gap and also for bridges between generations of grandfathers and grandchildren. These gaps and bridges are being built and sustained along the borders of ethnicity. March 16 has been reshaped from a commemoration date of the Latvians who were forced to join the SS troops into a day of national unity and collective memory day. I would even suggest this day has become a day of ethnic consolidation via ethnic memories and collective traumas and in this function the commemoration process is turned into political event which serves aims of acquiring symbolic capital and dominance over past interpretation - Pierre Bourdieu's formula explaining struggle for discursive control of reality is well applied to the current inter-ethnic communication in Latvia.

Following the ideas of Jan Assman, who has been influenced by the works of late Nora and his project "Places of memories", we may define the "Träger" of the Latvian collective memories of the World War II and post war period, including the period of independence since early 1990ies - these are various groups. First of all these are participants of the everyday oral history - veterans. Their grandchildren are now coming of age and even become active politicians, such as a member of the government coalition, "National Union" and its youth part - "All for Latvia". These politicians make up another group of bearers of communicative memory, among whom one of the most successful is a politician Raivis Dzintars, are regularly participating in the march of the Legion veterans on March 16.

It is necessary to add that this discourse of collective trauma presupposes the construction of collective responsibility - in Latvian case this is being ascribed by the right wing political discourse to an abstract ethnic Other, minorities or in political slang the Russians in Latvia. The fact that ethnicity and not political regime or ideology has become the term for a group whose collective responsibility is defined by Latvian political discourses shapes various integration issues: there are still about 300000 non-citizens in Latvia and the naturalization tempo is slowing down each year. ${ }^{21}$ (last viewed 5.01. 2013.) The recently adopted "State Programme for Integration (2012-2018)" has been already criticized by me in various articles, but the major deficit should be mentioned repeatedly - the idea of the Latvian nation is still not inclusive, the predominant idea of the state programme is to reestablish justice in the history of ethnic Latvians and to unite Latvian population on the basis of ethnic culture. Thus the hierarchy of the new state policy paper was immanent, and the former minister of culture Sarmite Ëlerte (Party "Unity") formulated this idea by the term "state shaping nation" which includes only ethnic Latvians - all other groups may become a part of Latvian cultural frame, but from the very beginning there is only one group which forms the state and is symbolically in charge of the statehood of Latvia. ${ }^{22}$

The so-called Other in the Latvian ethnic memories are ethnic minorities. Latvian minorities are far from being a homogenous group, both in their collective memories and in their experience of integration, although in everyday political discourse most ethnic non-Latvians are usually signified by Latvians as Russians and the same label is attached to various minorities by Russian political NGOs. Ethnic Russians are still predominant among non-citizens, but Roma, Jews, Poles and Ukrainians all differ from the Russian minority: for example almost all Roma are Latvian citizens and are fluent in Latvian. To make the ethnic landscape even more complicated, the pre War minorities differ from those, who came after 1945 - there are for example Old Believers, who are a unique combination of religious and ethnic group.

\footnotetext{
${ }^{21}$ Non-citizens in Latvia are not allowed to participate in both municipal and parliamentary elections. The Law on Citizenship has created positive framework for naturalization, but the number of naturalized citizens is growing very slowly. In 2005 there were 19000 naturalized, but in 2011 only 2467. For the latest data on non-citizens in 2012 see website of the State Citizenship and Migration Office: http://www.pmlp.gov.lv/lv/statistika/Naturalizacija.html.

22 State programme for National Identity, Civil society and Integration Politics is available in Latvian at: http://www.pmlp. gov.lv/lv/statistika/Naturalizacija.html (last viewed February 12, 2013).
}

00012-p.5 


\section{SHS Web of Conferences}

Various researchers have been analyzing social profiles of Russian-speaking minorities since the mid of 1990ies. ${ }^{23}$

V. Zelče stated that during the 1990ies Russian-speaking collective identities have been shaped by two major tendencies, both inherited from the Soviet ethnic policy, which, according the Jeffrey Hosking has created a dominant Russian ethnic-social group in all Soviet republics thus preparing latent inter-ethnic conflicts during the collapse of the Soviet empire. ${ }^{24}$ The first tendency was alienation from Latvian ethnic and linguistic space ${ }^{25}$ - an interviewed person Anna, 31 years old, Russian, living in Riga, confessed that during her childhood and teenager age (end of 1980ies) she lived in one of the so-called "sleeping districts" at the outskirts of Riga, a district built in the early 1980ies and inhabited mainly by ethnic minorities, and "had no idea that Latvians existed." 26 This remark may be used to illustrate not only an individual experience of cultural and communicative alienation, but may also serve as an explanation for the issue of Latvian language proficiency in the 1990ies which lasts until present day although the situation changes for the better and more and more non-Latvians speak Latvian and use it in the everyday life ${ }^{27}$, linguistic skills do not necessarily add to the feeling of belonging or opening up one's identity to other cultures. Following the concept of community as disturbing factor of the state policy, formulated by Homi K. Bhabha ${ }^{28}$, we may suggest, that position of ethnic minorities in ethnic Latvian discourses is shaped by two factors: their "origin" from the USSR as non-Western, non-democratic and "non-modernised" state and by collective imagination of Latvians suffered from Soviet occupation. Another useful argument by Bhabha is linked to post-colonial theoretical frame - colonised communities refuse to participate in the state affairs as its subjects. ${ }^{29}$ This refusal of civic participation shaped Latvian intellectual opposition to the Soviet regime, but may as well be characteristic of a certain community in a democratic society - in Latvia de-colonisation of post Soviet ethnic Latvian community called de-sovietisation, was followed by rapid transformation of former Soviet Russians into minorities, held responsible for the Soviet period and communism regime. The experience of becoming minority, large part of which also became non-citizens (in 2012 about 14\% of Latvian population are still non-citizens, among them about $65 \%$ are ethnic Russians), as well as predominant negative right-wing Latvian political discourse shaped by mistrust and negative images of ethnic Other can be interpreted in terms of symbolic re-colonization, led by Latvian political discourse towards ethnic minorities. In this case growing local conservative Russian nationalistic discourse which is becoming more and more visible, especially in cyberspace, may be interpreted in Bhabhian terms - as refusal to support a nation state and its politics, such as institute of naturalization, participation in Latvian ethnic culture, Latvian language expansion among minorities. Such ways of refusal are characteristic of minorities in societies, where majority political discourses tend to use exclusion techniques as a form of creating omnipresent majority culture. This type of modernization can be explained with concept of Frederick Cooper, who states that modernisation may cause frustrations and fears, when communities perceive themselves as being at risk of loosing their identities. ${ }^{30}$ To go one step further, we may state that Latvian minority conservative

\footnotetext{
23 To mention the most significant studies of the last decade: Apine I., Volkovs V. Latvijas krievu identitāte. Vēsturisks un sociologisks apcerējums. - LU Filozofijas un socioloìijas institūts: Rīga, 2007.; Šūpule I., Krastina L. et altera Etniskā tolerance un Latvijas sabiedrības integrācija. - Rīga: BSZI, 2004.; Zepa B., Šūpule I. et altera Etnopolitiskā spriedze Latvijā: konflikta risinājuma meklējumi. - Rīga: BSZI, 2005.

24 For detailed analysis see: Hosking G. Rulers and Victims. The Russians in the Soviet Union. - Cambridge, 2006. - p. 140, 163, $190,365,405$.

25 Parskats par tautas attīstību 2011 - 1pp. 41.

26 Name changed, partly structured interview took place in Riga on January 12, 2013 and lasted for 37 minutes.

27 For the role of the Latvian language proficiency in integration politics see: Djačkova S. Latviešu valodas zināšanas un sabiedrības integrācija. - Rīga: PROVIDUS, 2004.; Veisbergs A. Latviešu valoda - pastāvīgā un mainīgā. - Rīga: Valsts valodas komisija, 2007.

28 Bhabha H. K. The Location of Culture. - New York: Routledge, 1994. - p. 330.

29 Ibid.

30 Cooper Fr. Kolonialismus denken: Konzepte und Theorien in kritischer Perspektive. - Frankfurt: Campus, 2012 . - S. 202.
} 


\section{Int. Conf. SOCIETY. HEALTH. WELFARE.}

discourse, which will be touched upon further, is growing, but inclusive discourse is rapidly disappearing - both processes signify insufficient political will of ethnic majority elites to create inclusive discourse for Latvian society after the breakdown of the USSR. In the beginning of the second decade of the 21 st century Bhabhian refusal of community has grown and has got its communicative forms, bearers and time concept in the referendum in February 2012, in new minority conservative political party "ZARJA", in website "Rodina.lv" and other forms ${ }^{31}$. In these elements the non-acceptance of Latvian dominant politics towards minorities is becoming heavier, more stable and less able to alter.

Another tendency during the Soviet regime was the belief into the Soviet version of the Latvian history, transmitted and sustained by decades of falsified Latvian history in the school books, university lectures and public media, including cinema. This is another vital element of the refusal described above. The author of this article remembers his own school years when Latvian history in the $20^{\text {th }}$ century was defined as the way through bourgeois and militant pro-fascistic regime of the late president Kārlis Ulmanis, ${ }^{32}$ until the Latvian communist party, which was forbidden during the regime of Ulmanis finally overthrew the regime and proclaimed the Soviet republic - this was the official Soviet version of what is known as Molotov-Ribbentrop pact which divided Poland and the Baltics before the advent of the Second World War. The pact became known in the late 1980ies and has become the major proof of the false interpretation of Latvian history during the occupation regime. This document and the historic fact of aggression and not "joyous joining of the family of Soviet republics" as Soviet pupils were taught, became the major act of symbolic alienation of minorities during the 90ies. During the preparation campaign for the collection of signatures for the referendum on the status of Russian language in Latvia in November 2011, among some of the conservative diaspora groups of Russian minorities the non acceptance of the fact of occupation became one of the most effective tools for public mobilization of voters. It is of interest, that the Internet space is predominantly occupied with the issues of identities as conflicting political agents - for example the website of NGO "Rodina.lv" [motherland.lv in Russian] echoes the idea of the "state nation" in the above mentioned state policy paper for integration and provides a memory-shaped emotional answer for the thesis by Ministry of Culture : "Latvia is a two communities state and Russians are one of the two state shaping communities." 33 The manifesto states that two groups are integral and equal parts of the state and there are no minorities as such, but there are Russians (the manifesto also states that in the modern world the ethnicity is of no importance).$^{34}$ Among other products of collective memory formulated in the text are the following visions of the Latvian Russians: Russian assisted Latvians in their coming into status of a nation. But the most radical rejection of European and Latvian academic research and archive documents on the causes of Latvian occupation is the following part of the manifesto under the title: "Was there the occupation of Latvia?":

\footnotetext{
31 The question remains open whether elements of the minority discourse mentioned are right, conservative or left wing with radical elements in it. One of the prominant figures of the party "ZARJA" Andrey Berdnikov stated in his recent interview, that this division is outdated. He defined the party as "positive populist" movement againts elites. See: Berdņikovs A. Vēlos spraigākas un provokatīvākas diskusijas. // Latvijas Avīze, 07.01 .2013$. http://la.lv/index.php?option=com_content\&view=article\&id=369546:berdikovs-vlos-spraigkas-un-provokatvkas-diskusijas (last viewed 9.01. 2013.)

32 Kārlis Ulmanis was the last president of Latvia before occupation in 1940. He seized the power and became an authoritarian leader of the state, called Vadonis in May 1934 after coup supported by militia and army, as well as by massive positive support of the majority of the population. Ulmanis remained president until July 1940 and was later arrested and deported to the inner provinces of the USSR where he died in a prison hospital. See more on this period of Latvian history in the latest publication in English: Hanovs D., Tēraudkalns V. Ultimate Freedom-No Choice. Culture of Authoritarianism in Latvia, 1934-1940. - Holland: Brill, 2013

33 Manifest: Latvijskije russkije v voprosah I otvetah: http://rodina.lv/manifest/1-manifest (last viewed 10. 01. 2013.)

34 Ibid.
} 
In 1940, the Republic of Latvia, which existed since 1918 following the decision of its parliament, ${ }^{35}$ joined the USSR. The Soviet troops were stationed following the acceptance by the president Kārlis Ulmanis. ${ }^{36}$

This vision of the Latvian past can be explained in terms of cultural translation, which, according to Bhabha "desacralizes" the transparent assumption of cultural supremacy..."37 - in this particular case desacralization or in Bhabha's vocabulary "blasphemie" is to name judicial acts of illegal pro-Soviet parliament as legal, thus symbolically cancelling occupation through making it the decision made freely by representatives of Latvian population in 1940.

Bhabha states in various places the role of performance in cultural communication ${ }^{38}-$ this thesis can be described by various actions of minority activists on dates which not only commemorate events (wars, victories, death or birth of charismatic persons of the past, etc.) but are becoming translation tools for local minorities in finding their identities in Latvia.

Translational version of the Latvian past where minorities may discover upgrade of their social image, finds its visual articulation during the commemoration of another "problematic" date - May 9, the end of the Great Fatherland War in the Soviet Union. Each year veterans of the Soviet army, together with their relatives and politicians from party union "Harmony" (Saskana) gather in front of the statue of "Liberators of Riga" - the ensemble of Red Army soldiers erected during the Soviet period on the spot where the so-called "Square of Victory" during the late 1930ies was used for festive occasions of the regime of Kārlis Ulmanis. These annual gatherings are visited also by the representatives of the Riga Council, including a Russian mayor Nil Ushakov. This young mayor was in favour of Russian language campaign and set his signature for the referendum. At the same time the fewer Soviet veterans there are, the more youngsters, the generation of their grandchildren are present during the celebrations on May 9. As You tube videos show, certain kind of inter-generational bridge has been established recreating or staging the Soviet past - with red flags and youth guard who carries these flags and are proud of their grandfathers. ${ }^{39}$ At the same time simultaneous presence of Russian celebration in Moscow is available via satellite TV broadcast on wide screens located in the area of the monument. Another element of the concept of glorious past of the ethnic minorities is that the modern Russia took over from the Soviet Union the paradigm of the winner of the fight against fascism, who carried the most casualties and deaths - this image is being used in the current so-called "anti-fascist" concept which is staged annually during the protests against the march of the Latvian legion veterans - activists dressed up like concentration camp prisoners shout various critical comments during the march. The Latvian television and predominantly Latvian-speaking printed media depict the festivities of May 9 at the monument in rather pejorative way, focusing visual aspects on vodka, herring and dances with war time songs - long lasting media content analysis conducted by me during the last 5 years of celebrations support this suggestion of the techniques of eliminating the Other through laughing at the "sacred" images of the Other. Russian embassy in Latvia still acts as an important external actor of the internal Latvian debates on the politics of the past - when the Catholic archbishop of Latvia Zbignsevs Stankevičs suggested in spring 2012 the idea of creating one commemoration day for all Latvian war veterans who did not fight for their country but were soldiers in two foreign armies, the Russian Foreign Ministry

\footnotetext{
35 The Parliament was elected after Soviet troops entered Riga and the president was forced to allow parties, including communist party. The parliamentary elections under the supervision of Soviet security police were not accepted as free and democratic in Europe and the USA later declared that it does not recognize the incorporation of Latvia into the USSR.

36 Ibid.

37 Bhabha H. K. The location of Culture...- p. 327.

38 Ibid. - p. 326.

39 Video of the celebrations on May 9, 2011 in Riga: http://www.youtube.com/watch?v=D_rpJWPbWnI (last viewed 14 January 2013).
} 


\section{Int. Conf. SOCIETY. HEALTH. WELFARE.}

reacted with sharp critics, accusing the archbishop of an attempt to equate Soviet veterans with Legion veterans. ${ }^{40}$

To sum up some of the examples of parallel interpretations of the Latvian past, the following should be stated: firstly, there are two parallel ethnically shaped realities in the interpretation of the $20^{\text {th }}$ century history in Latvia. Secondly, the state and academicians are not able to compete with the media shaped products of the collective identities and history interpretation - these are the media of collective emotions. Thirdly, collective memories in both "groups" of ethnically divided society are sustained and re-produced using generational bridges - beliefs in one's ethnic version of Latvian history are acting as unifying elements of identities over generational changes and controversies. Past is what shapes ethnically divided youth and builds bridges over generations within one ethnic group.

New technical tools, such as internet websites, chats or other social networks are used to come back to the past of one's own ethnic memories which in return produce meanings, explain social division and even judicial differences between citizens and non-citizens. Technical tools may vary, but these "memory devices" do not create generation gaps when ethnicity in concerned. On the contrary, collective memory can overcome obstacles created on its way by history as science. Political and media discourses provide far more appealing versions for believing, not analysing one's ethnic identity of which past is an integral part.

\section{References}

[1] Assmann J. Das kulturelle Gedächtnis. Schrift, Erinnerung und politische Identität in frühen Hochkulturen. - München: Becksche Reihe, 1997.

[2] Bhabha H. K. The Location of Culture. - New York: Routledge, 1994.

[3] Cooper Fr. Kolonialismus denken: Konzepte und Theorien in kritischer Perspektive. - Frankfurt: Campus, 2012.

[4] Erll A., Nünning A. (eds.). A Companion to Cultural Studies. - De Gruyter, 2010.

[5] Hanov D., Tēraudkalns V. Denying the Other in the Cyber Space: Democracy and Political Culture in Latvia: Analysis of the Internet Campaign "For Mother Tongue" (November 2011)// Ethnicity 2012/6.

[6] Hanovs D., Tēraudkalns V. New Diaspora Nationalism in Latvia? Russian Identity in Internet Campaigns "For Mother Tongue" (2011) and "Change the Law on Citizenship" (2012) // Scientiae et Patriae. Veltījums akadēmiķei profesorei Vairai Vīksei-Freibergai 75. dzimšanas dienā. / Cimdiņa A., sast. Rīga: LU Akadēmiskais apgāds, 2012.

[7] Kaprāns M., Zelče V. (eds.) Pēdējais karš: atmiņa un traumas komunikācija. - Rīga: Mansards, 2011.

[8] Latvija. Pārskats par tautas attīstību 2011. - Latvijas Universitāte.

[9] Muižnieks N., Zelče V. (eds.) Karojošā piemiņa. 16. marts un 9. maijs. - Rīga: Zinātne, 2011.

[10] Nora P. Zwischen Geschichte und Gedächtnis. - Frankfurt am Main: Fischer, 1998. - S. 13-14.

[11] Radstone S., Schwary B. (eds.) Memory. Histories, Theories, Debates. - Fordham University Press, 2010. - pp. 77-92.

[12] http://www.lsif.lv.

[13] Halbwachs M. Collective Memory. See Chapter 5 of on-line version: http://web.mit.edu/allanmc/ www/hawlbachsspace.pdf.

[14] http://www.biss.soc.lv.

[15] http://puaro.lv.

[16] http://rodina.lv.

\footnotetext{
40 http://puaro.lv/lv/puaro/krievija-sasutusi-par-stankevica-domu-apvienot-16marta-un-9maija-svinetajus (last viewed 15. January 2013).
} 